\title{
INCIDENCE AND FUNCTIONAL EVOLUTION OF TRAUMATIC INJURIES OF THE SPINE
}

\author{
INCIDÊNCIA E EVOLUÇÃO FUNCIONAL DE LESÕES TRAUMÁTICAS DA COLUNA
}

INCIDENCIA Y EVOLUCIÓN FUNCIONAL DE LESIONES TRAUMÁTICAS DE LA COLUMNA VERTEBRAL

Francisco Alberto Trinidad Ovalle ${ }^{1}$, Elibardo Cuellar Ríos ${ }^{1}$, Fernando Ruiz Balbuena ${ }^{1}$

\begin{abstract}
Objective: To determine the incidence and functional outcome of traumatic injuries of the spine in the period from January 1,2013 to December 31, 2013, at the General Hospital "Dr. Rafael Pascacio Gamboa", state of Chiapas, México. Methods: A retrospective, cross-sectional, descriptive, observational study, where all patients seeking medical and surgical care in the emergency department and inpatient unit for a traumatic spinal injury were included, regardless of age or sex. Results: A sample of 60 patients, of whom 43 were male (71.7\%) and 17 females (28.3\%), with an average age of 35 was obtained. As for the cause of the injury, falls were the leading cause (61.7\%) followed by motor vehicle accidents (35\%) and finally, assaults (3.3\%). In this sample, $21 \%$ had associated injuries being the most common (7.3\%) the thoracic trauma. The most common site of injury was the thoracic spine, followed by the lower cervical and finally the thoracolumbar ones. We found that $70 \%$ of patients had partial or complete neurological injury, with complete spinal cord transection (Frankel A) being the most frequent lesion in 53\%. Conclusion: The incidence in our series is similar that the reported in developing countries which have sociocultural problems similar to ours. The same applies to the etiology of these lesions, which is closely linked to social and economic activity in each country or region.
\end{abstract}

Keywords: Spinal fractures; Spinal cord injury/etiology; Retrospective studies.

\section{RESUMO}

Objetivo: Determinar a incidência e evolução funcional de lesões medulares traumáticas no período de 01 de janeiro de 2013 a 31 de dezembro de 2013, no Hospital Geral "Dr. Rafael Gamboa Pascacio" estado de Chiapas, México. Métodos: Estudo retrospectivo, transversal, descritivo e observacional, onde foram incluídos todos os pacientes que procuraram atendimento médico-cirúrgico na unidade de pronto-socorro e hospitalar, independentemente de idade ou sexo, que tinham lesão traumática na medula espinhal. Resultados: Obteve-se uma amostra de 60 pacientes, dos quais 43 eram homens (71,7\%) e 17 mulheres (28,3\%), com média de idade de 35 anos. Quanto à causa da lesão, as quedas foram a principal causa (61,7\%), seguidas de acidentes com automóveis (35\%) e por agressões (3,3\%). Do total, $21 \%$ dos pacientes tiveram lesões associadas, sendo a mais comum o trauma torácico (7,3\%). O local mais comum de lesão foi a coluna torácica, seguido pela cervical baixa e, finalmente, a coluna toracolombar. Verificamos que $70 \%$ dos pacientes tiveram lesão neurológica total ou parcial, sendo a transecção completa da medula espinhal (Frankel A) a lesão mais frequente (53\%). Conclusão: A incidência em nossa série é semelhante à relatada em países em desenvolvimento que têm problemas socioculturais semelhantes aos nossos. O mesmo se aplica à etiologia das lesões, que está estreitamente ligada à atividade econômica e social de cada país ou região.

Descritores: Fraturas da coluna vertebral; Traumatismos da medula espinal/etiologia; Estudos retrospectivos.

\section{RESUMEN}

Objetivo: Determinar la incidencia y evolución funcional de las lesiones traumáticas de la columna vertebral en el periodo comprendido del 01 de enero del 2013 al 31 de diciembre del 2013, en el hospital General "Dr. Rafael Pascacio Gamboa" del estado de Chiapas, México. Métodos: Se trata de un estudio retrospectivo, transversal, descriptivo y observacional, donde se incluyeron a todos los pacientes que solicitaron atención médico-quirúrgica en el servicio de urgencias y hospitalización de la unidad, sin importar edad o sexo que presentaron una lesión vertebral traumática. Resultados: Se obtuvo una muestra de 60 pacientes, de los cuales 43 eran del sexo masculino (71,7\%) y 17 del sexo femenino (28,3\%), con un promedio de edad de 35 años. En cuanto a la causa de la lesión, las caídas ocuparon el primer lugar $(61,7 \%)$ seguidas de accidentes automovilísticos (35\%) y en tercer lugar las agresiones (3,3\%). El 21\% presentaron lesiones asociadas siendo el trauma torácico el más frecuente (7,3\%). El sitio de lesión más habitual fue la columna torácica, seguida de la cervical baja y finalmente las toraco-lumbares. Encontramos que el $70 \%$ de los pacientes presentaron lesión neurológica parcial o completa, siendo la sección medular completa (Frankel A) la lesión más frecuente en un 53\%. Conclusión: La incidencia encontrada en nuestra serie, es similar a la reportada en países en vías de desarrollo quienes cuentan con una problemática sociocultural similar a la nuestra. Lo mismo sucede con la etiología de estas lesiones, la cual se encuentra estrechamente ligada a la actividad social y económica de cada país o región.

Descriptores: Fracturas de la columna vertebral; Traumatismos de la médula espinal/etiología; Estudios retrospectivos.

\section{INTRODUCTION}

Acute spinal injury is a devastating and disabling life event. According to figures from the United States, there are around 11,000 acute spinal injuries each year, and more than 250,000 individuals are living with the consequences of these injuries. ${ }^{1}$ The average age at which these injuries occur is 38 years, although the most severe injuries occur in adolescents and young adults in motor vehicle accidents involving high-powered cars, presumably as a result of a

1. Hospital Rafael Pascácio Gamboa, SSA of the State of Chiapas, Mexico.

Study conducted at the Orthopedic Service of Hospital Rafael Pascacio Gamboa, SSA, of the State of Chiapas, Mexico.

Correspondence: Servicio de Ortopedia del Hospital Rafael Pascacio Gamboa, SSA del estado de Chiapas, Mexico.9616031217. ovalle707@hotmail.com 
bad combination of inexperience, recklessness, alcohol and/or drugs, affecting the victims at the most productive stage of their lives. ${ }^{2}$

Studies in the literature report that traumatic vertebral injuries are more common in young, economically active men, with the primary causes being falls from heights and traffic accidents. The reported worldwide incidence ranges from 16.6 to 40 patients per million inhabitants. ${ }^{3-5}$ Approximately $50 \%$ of spinal injuries are quadriplegic. ${ }^{6}$

The incidence in a specialized hospital in the Federal District is 1.77 OK per 100,000 claimants. ${ }^{7}$ The demographic characteristics of the patients are as follows: $79 \%$ men and $21 \%$ women, with a male to female ratio of 4 to 1 , an average age of 36 years, with a mode of 18 and a median of $33.8-10$

Now the question is: What are the incidence, etiology, kinematics, and functional evolution of patients in our population who underwent medico-surgical treatment for spinal injuries?

Today, we are facing rapid development in our cities, making life more frenetic and dangerous - a situation that directly and indirectly impacts both the frequency and severity of traumatic injuries. ${ }^{11}$

Among them, injury of the spinal cord with loss of neurological function is the most devastating life-changing injury that a doctor and a patient can face. ${ }^{12-14}$

In a review of the international literature, we found that in the United States, spinal cord injuries occur at an annual rate of 30 cases per million inhabitants, which translates into 8000 new cases per year. ${ }^{15-17}$

We also see that the etiology of these injuries varies depending on the social, economic, and geographical environments of the population being studied. For example, in more socioeconomically developed cities, we find falls from heights and traffic accidents as the most common causes of injury, compared to other locations, where the main causes of traumatic vertebral injuries involving the spinal cord are related to wounds from firearm projectiles. ${ }^{18,19}$ What makes a difference in terms of the etiology of the injury is linked to the social, political, economic environment of each place..$^{20}$

The Rafael Pascacio Gamboa regional hospital is a second level regional hospital with a spine surgery service that, though not typical of the national reality, serves patients from throughout the State of Chiapas.

Most of the injuries are preventable, which is easier and less expensive than treating the damage caused by a spinal injury. Preventive studies have recognized the importance of monitoring incidence because without this data, it is impossible to evaluate the effectiveness of prevention efforts. ${ }^{21,22}$

The current panorama of diseases of the spine has demonstrated its importance and its impact on institutional policies, and both prevention and the adequate strengthening of institutional resources are essential to improving diagnosis, management, and prognosis of this segment of the population. Thus, a study that includes official data over a long period of time can be considered foundational for planning and forecasting the resources to be allocated to this group of patients. ${ }^{23,24}$

\section{MATERIAL AND METHODS}

This is a partial, retrospective, descriptive, cross-sectional, observational study. Study universe: All patients who were treated in Emergency and Hospital Admission regardless of age or sex, in the corresponding period. Inclusion criteria: A) Patients with traumatic vertebral injuries with or without neurological damage treated in the Emergency or Hospital Admission units; B) Male and female patients of any age with traumatic vertebral injuries. Exclusion criteria: A) Patients with traumatic vertebral injury who requested voluntary discharge or transfer to another medical unit; B) Cervical sprains managed in outpatient emergency services. Data collection was performed using an automated data collection (calculation) sheet in which all the socio-demographic parameters were captured, as well as information about the diagnosis, treatment, evolution, etiology, and resolution of each patient in the sample. The study was authorized by the Bioethics Committee of our hospital, under authorization number 1006

The Frankel classification for the evaluation of neurological state and the $\mathrm{AO}$ (universal classification of the working group of the Association for the study of Internal Fixation) were used to stage the type of fracture. The etiology of the injuries was classified as either a fall, a traffic accident, or aggression. For the distribution by vertebral segment, the spine was divided into three regions: cervical, thoracic, and lumbar. The cervicothoracic (CT) and thoracolumbar (TL) transition zones were also included as independent regions in injuries that involved these vertebral segments.

The information obtained was loaded into a database using various statistical programs (EPIINFO, Excel). Once the database was built, univariate (descriptive) analysis of the characteristics of the study population was performed. Percentages, averages, and standard deviations were calculated. Later bivariate analysis was performed using the chi square test for qualitative variables and the Student's t test for the quantitative variables.

To determine the incidence of a particular injury, all new cases produced in a specific population have to be identified during a specific period of time. In the clinical study, several new cases were identified, but the population in which they occurred could not be identified, a factor that prevented precise calculation of the incidence rate. The incidence rate was calculated for the general population implicitly, assuming that all individuals are at risk and therefore, we used the population assigned to the unit on the assumption that traumatic injuries are sent to this unit.

\section{RESULTS}

We obtained the records of a total of 60 patients diagnosed with traumatic vertebral lesions during the period January 1, 2013 to December 31, 2013. From the socio-demographic characteristics, we observed that $43(71.7 \%)$ of the patients were men and $17(28.3 \%)$ were women. The patients' ages ranged from 16 to 84 years, with a median age of 35 years. The age group with the largest number of patients was the 31-45 years old group.

In terms of level of education of the participants, $11.7 \%$ were illiterate, $21.7 \%$ had college degrees or equivalent, $40 \%$ had completed elementary school, $25 \%$ had completed high school, and $1.7 \%$ licenciate degrees.

An analysis of the different job categories showed that the most impacted group in the general sample was office workers (46.7\%), followed by laborers (33.3\%), then professionals (8.3\%), housewives (6.7\%), and students (5.0\%). In an analysis by sex, we observed the following variations:

As for the distribution of the injuries by vertebral segments, there were 23 thoracic (83.3\%), 15 lower cervical (25\%), 10 thoracolumbar (16.7\%), eight lumbar (13.3\%), and four upper cervical $(6.7 \%)$ injuries. (Figure 1)

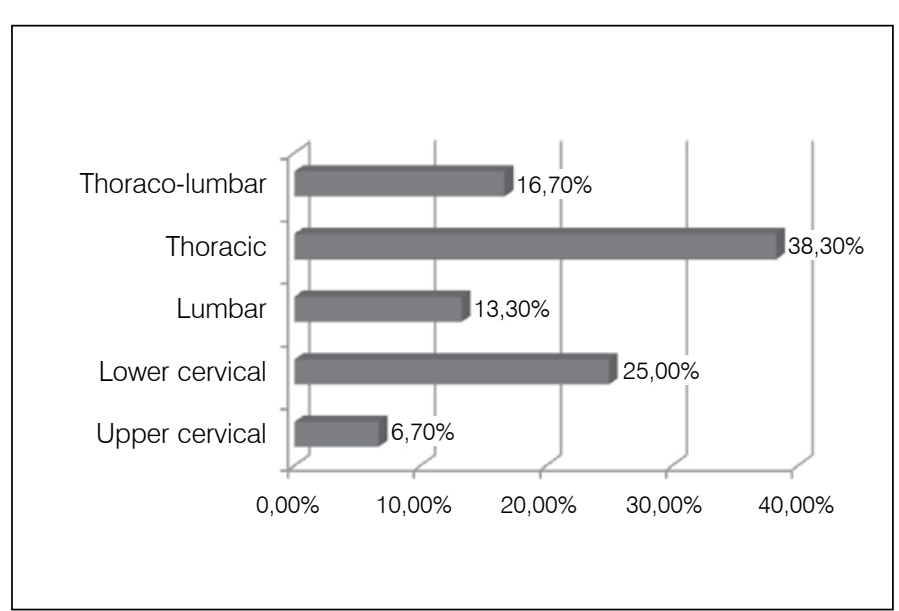

Figure 1. Distribution of injuries by vertebral segment. 
In terms of the traumas that caused the injuries, falls were the most common, with 37 patients $(61.7 \%)$ of whom 17 fell from 3 or more meters in height (47.2\%), 16 fell from less than 3 meters in height (44.4\%), and three were fell from their own height (8.3\%). Falls were followed by traffic accidents with 22 patients (35\%), of whom 20 were inside the vehicle (90.9\%) and two were run over $(9.1 \%)$. Finally, there were two patients with injuries from aggression (3.3\%) caused by FAPs. (Figure 2)

According to the Universal Classification System of the working group of the Association for the Study of Internal Fixation (AO), 33 were in category B (55\%), followed by category A with $14(23.3 \%)$, and finally category $C$ with 13 patients $(21.7 \%)$. On the Frankel scale, these injuries presented Frankel A neurological compromise in 32 patients (53.3\%), Frankel $E$ in 17 patients (28.3\%), Frankel B and C in four patients each (6.7\%), and Frankel $\mathrm{D}$ in three patients (5\%). (Figure 3 )

According to the $\mathrm{AO}$ classification for fractures, we found that 14 patients belonged to group A (23.3\%), of which A 1.2 was the most common, with four patients (28.6\%).

Among fractures of type B, which corresponded to $55 \%$, we found that the B 3.3s were the most frequent with 11 patients (34.4\%). There were 14 patients $(21.7 \%)$ in category $\mathrm{C}$, with 7 fractures of type C 2.1 (50\%) occupying first place.

Among the injuries associated with spinal pathology, thoracic trauma was the most frequent, with 4 patients (7.3\%), followed by fractures of the upper limb in three cases (5.5\%), cranioencephalic traumatisms in three cases (5.5\%), and finally fractures of the upper limb in three cases (5.5\%). (Figure 4)

Of the total of 60 patients in the sample, 39 patients $(65 \%)$ resumed their daily activities and 21 patients (35\%) were not able to, due to some form of disability. 14 patients returned to work following surgery (23.3\%) and 46 patients could not (76.7\%).

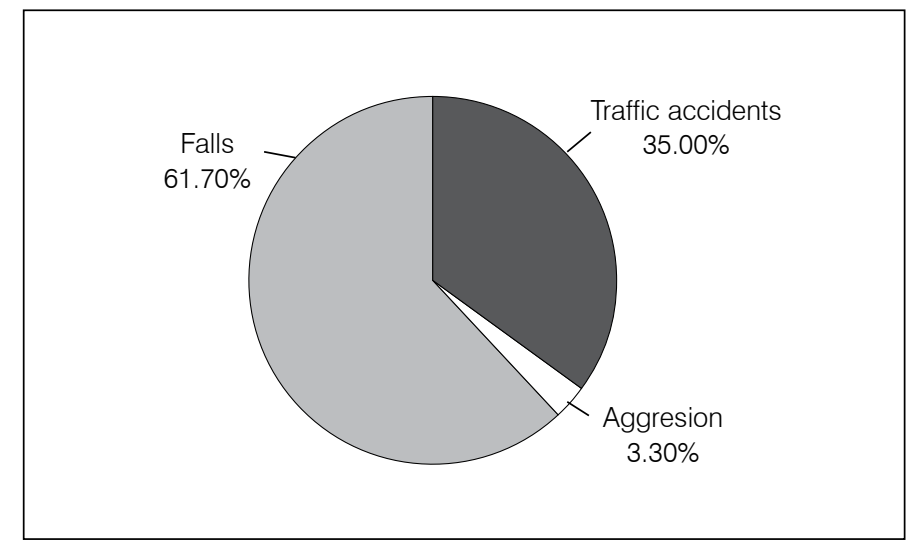

Figure 2. Distribution of the patients with traumatic vertebral injury.

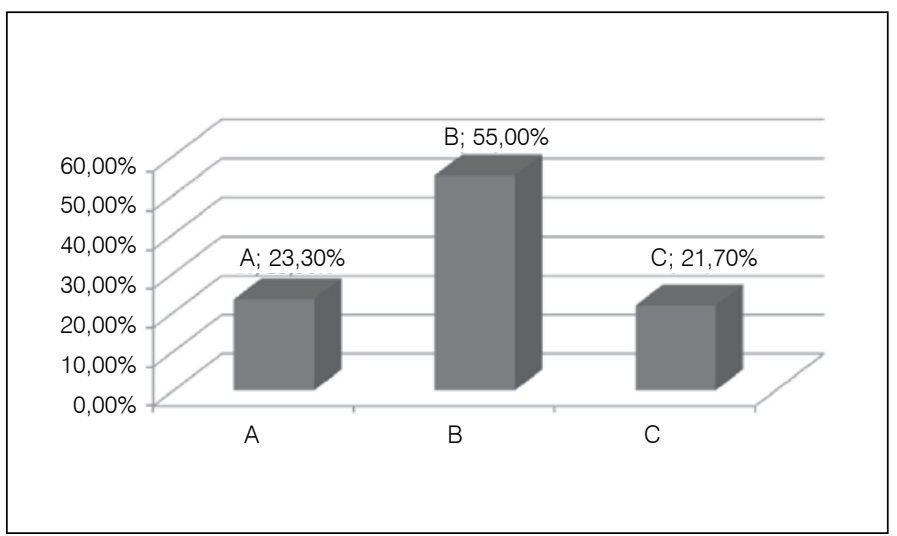

Figure 3. Classification of the fractures according to the Association working group for the study of internal fixation of fractures. (AO).
In an analysis by sex, we observed the following variations: the higher risk groups among men are office workers (46.5\%) and laborers (46.5\%), compared with the women, among whom office workers (47\%) and professionals (29\%) are the most affected.

The injuries presented neurological compromise in 43 patients $(71.6 \%)$ classified according to the Frankel scale, and there were 17 patients without any neurological impact (Frankel E - 29\%). (Figure 5)

The Frankel A complete neurological injuries (53\%) included 14 thoracic, 10 lower cervical, three lumbar, and one upper cervical injury. At the other end of the spectrum, there were eight thoracic and nine lumbar injuries without any neurological compromise.

In the postoperative evaluation by age group, we found that among the patients aged $15-30,63.6 \%$ were in the Frankel scale functional category of sensory function only with complete absence of motor function (Frankel B), and that similarly, in the 31-45 and 45 and older groups, sensory function was preserved with the absence of motor function (Frankel B), corresponding to 29 patients (48\%).

In the functional group without neurological injury, there were five patients in the 15-30 group (5\%), nine patients in the 31-45 group (33\%), two patients in the 46-65 group (25\%), and two patients in the over 65 group (25\%), with a total of 18 patients, corresponding to $30 \%$ of the total sample.

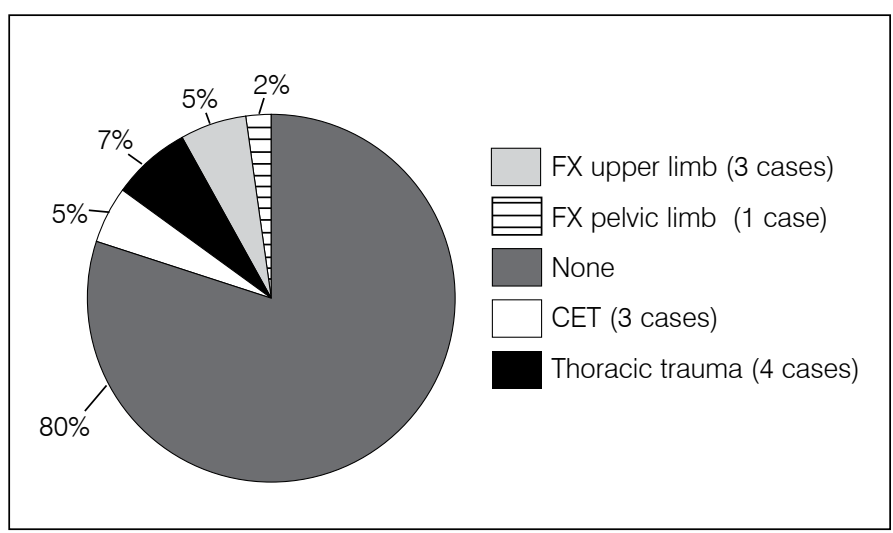

Figure 4. Injuries associated with traumatic vertebral fractures.

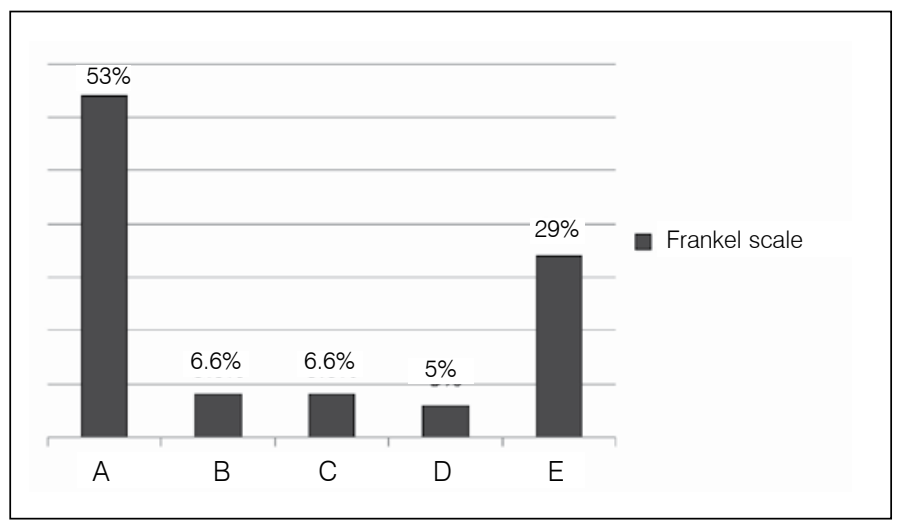

Figure 5. Patients with vertebral injuries, according to the Frankel scale.

\section{DISCUSSION}

Traumatic spinal injuries are certainly a risk that we face every day. Unfortunately, injuries accompanied by spinal cord damage are one of the most debilitating pathologies that a patient and a doctor can face. ${ }^{25}$

The average patient age is 35 years, with the $31-45$ years of age group being the most affected age group and with a higher percentage of men impacted, and for women this age group is from 43-17 years, a situation reflecting a difference in terms of the risk groups 
of young working-age male patients and women from 15-30 years of age in professional jobs. These are patients in their productive years, who are at a greater risk of traumatic spinal injuries, which translates into a social and economic impact within the population equal to that reported in the universal literature. ${ }^{26}$

The life expectancy in the USA for this group of patients has increased, thanks to advances in treatment techniques, resulting in a life expectancy among young patients with paraplegia of around $90 \%$, and with quadriplegia of around $30 \% .{ }^{27}$ However, we must take into account that, given the educational and socioeconomic conditions of our country and our state, we cannot expect the same results, but we do not yet have enough information. ${ }^{28}$

An analysis of vertebral injuries by segment showed that the most affected spinal zone was the thoracic, followed by the lower cervical, and finally the thoracolumbar junction. These results do not agree with those reported in the literature in which the most injured region is the cervical, followed by the lumbar and the thoracic regions. ${ }^{29}$

The increase in the number of thoracic injuries in our study may be due to the fact that the leading cause of injuries was falls from height, which generally results in pathologies of this region. Another limitation may be that the population consists mostly of people employed in construction work, and of a low socioeconomic level.

On the other hand, we found that $72 \%$ of the population studied presented neurological compromises, including changes ranging from mild to total severing of the spinal cord. It is reported that approximately $50 \%$ of spinal traumas are accompanied by spinal cord damage. ${ }^{30}$ In our results, we found that among the patients with complete spinal cord injury (Frankel A 53.5\%), the most injured segment was the thoracic, followed by the lower cervical, and finally the lumbar segment.

Neurological injuries at the thoracic level are directly related to the low spinal reserve capacity in this anatomical region as compared with others, and to the amount of energy released to produce damage to the protection provided by the thoracic cage in this region. ${ }^{31}$ This is different from the cervical spine, which has a high spinal reserve but less protection given its location, putting it at greater risk of suffering injuries from lower energy traumatisms associated with traffic accidents. This was the second most common cause of injuries in our sample. ${ }^{32}$

The etiology of these injuries is closely linked to the social and economic activities of each country and region. ${ }^{33}$ In our sample, we found that falls are the main cause of injury, followed by traffic accidents, and finally, aggression. This goes hand in hand with the type of population that we serve in our hospital, which consists mainly of workers of a low socioeconomic level. $46.7 \%$ of them work as laborers.

In other countries like Japan and the United States, traffic accidents are reported as the primary cause, and sports injuries are among the top three. ${ }^{34}$ However, because of the type of population that comes to our hospital, we had no injuries that were secondary to sports traumas.

The level of education of the patients included in this study shows that most of them have minimum education, i.e. $40 \%$ of the people had only from one to six years of school, with a resulting preponderance of physical and manual labor activities. This group of people is at risk for this type of injury.

\section{REFERENCES}

1. Desai SS, Coumas JM, Danylevich A, Hayes E, Dunn EJ. Fracture of the occipital condyle: case report and review of the literature. JTrauma. 1990;30(2):240-1.

2. Martín-Ferrer S. [High cervical spine injuries: classification, therapeutic indications, and surgical approaches: 286 consecutive cases]. Neurocirugia (Astur). 2006;17(5):391-419.

3. Tejeda Barreras M. Esteroides en lesión medular postraumática aguda. Rev Mex Columna. 2011;1(2):39-42.

4. Cisneros-Dreinhofer F, Hurtado-Padilla A. Incidencia de las lesiones vertebrales traumáticas en el servicio de Cirugía de Columna de un hospital de concentración del sistema de seguridad social. Acta Ortop Mex. 2003;7(6):292-7.

5. Gómez Santa Cruz M. Prevalencia de las lesiones traumáticas y no traumáticas de columna en el centro Médico Nacional de Occidente: 10 años de estadística. Bol Ortop
Traumatic injuries in general are increasing day by day, as in the case of cranioencephalic traumatisms, which are the primary cause of associated injuries. ${ }^{35}$ We found that thoracic trauma was the primary cause of associated injuries in $7.3 \%$ of cases, followed by cranioencephalic traumatisms in $5.5 \%$, a finding that does not differ much from the international literature.

We found a mortality rate of $3 \%$, which is unfortunate, but nevertheless, we must emphasize that $97 \%$ of patients with traumatic spinal injuries survived, and they are the ones who suffer the consequences and require a better quality of life. If we compare our results with those reported in the international literature, we find that they are lower than the mortality rate reported, which varies between $7 \%$ and $26 \%$. But we must note that our report does not address follow-up of these patients, and they are eventually referred to other units for rehabilitation.

In this study we did not encounter any differences between the groups with respect to sensitivity or functionality scales in patients who began 48-hour treatment with methylprednisolone sodium succinate (MPSS) between 3 and 8 hours following the injury. Several associations, like the American Association of Surgeons (Guidelines of the AANS/CNS Joint Section on Disorders of the Spine and Peripheral Nerves), reviewed all the literature available to date and concluded that administration of MPSS, for either 24 or 48 hours, is a treatment option for patients with acute spinal cord injury that should only be used with knowledge of the evidence that suggests that the adverse side effects can outweigh the possible clinical benefits.

Others, like the National Association of Emergency Medical Services Physicians (NAEMSP), have reported that evidence of the use of steroids in high doses is not conclusive, and that treatment with steroids should not be regarded as the standard treatment. The routine use of steroids is not recommended by European emergency systems. $^{36}$

Based on this analysis, from a strictly scientific perspective, and taking into account evidence classified as Class I in the medical literature, the administration of methylprednisolone in patients with acute spinal cord injury is questionable.

This pathology is not one of the major foci of worldwide medical attention. However, the economic and social impact of injuries with neurological compromise have made this condition a health issue that must be addressed. The United States reports 8000 new cases each year, representing around four billion dollars in costs. ${ }^{37}$

In their review of traumatic vertebral injuries with neurological damage, Tyroch et al found that $74 \%$ of cases are potentially preventable. For this reason, the measures taken to treat these injuries should be focused on prevention, as this is the most concrete and feasible way to deal with this type of injury. ${ }^{37}$

The impact of epidemiology on knowledge of traumatic vertebral injuries is of utmost relevance for designing preventative strategies, because this type of problem goes beyond the individual and into the populational environment, which is the arena where changes in health care take place and where the benefits of preventive actions are shared.

All authors declare no potential conflict of interest concerning this article.
Traumatol CMNO. 2012;3(1):9-15

6. Marsh JL, Slongo TF, Agel J, Broderick JS, Creevey W, DeCoster TA, et al. Fracture and dislocation classification compendium - 2007: Orthopaedic Trauma Association classification, database and outcomes committee. J Orthop Trauma. 2007;21(Suppl 10):S1-133.

7. Granados Peña I. Monitorización electrónica en el análisis de la estabilidad de la columna lumbar posterior a una cirugía con y sin instrumentación transpedicular. Columna. 2011:1(3):44-51. Disponível em: www. columnaenlinea.com

8. Alpizar-Aguirre A, Elías-Escobedo A, Rosales-Olivares L, Miramontes-Martinez V, ReyesSánchez A. Síndrome de destrucción vertebral. Sistemas de evaluación en su diagnostico. Cir Ciruj. 2008;76(3):205-11.

9. Swett PP, Bennett GE, Street DM. Pott's Disease: the initial lesion, the relative infre- 
quency of the extension by contiguity, the nature and type of healing, the role of the abscess and the merits of operative and non-operative treatment. J Bone Joint Surg Am. 1940;22(3):878-94.

10. Yilmaz C, Selek HY, Gürkan I, Erdemli B, Korkusuz Z. Anterior instrumentation for the treatment of spinal tuberculosis. J Bone Joint Surg Am. 1999;81(9):1261-7.

11. Anderson PA, Moore TA, Davis KW, Molinari RW, Resnick DK, Vaccaro AR, Bono CM, Dimar JR 2nd, Aarabi B, Leverson G; Spinal Trauma Study Group. Cervical spinem injury severity score. Assessment of reliability. J Bone Joint Surg Am. 2007;89(5):1057-65.

12. Zhou F, Zou J, Gan M, Zhu R, Yang H. Management of fracture-dislocation of the lower cervical spine with the cervical pedicle screw system. Ann R Coll Surg Engl. 2010;92(5):406-10.

13. Cisneros FD. Tratamiento de las fracturas del segmento cervical inferior (c3 a T1). Ortho-Tips.2007:3(3):178-87.

14. Cisneros FD, Hurtado AP. Incidencia de las lesiones vertebrales traumáticas en el Servicio de Cirugía de Columna de un hospital de concentración del sistema de seguridad social. Acta Ortop Mex. 2003; 17(6): 292-7.

15. Ocampo Román RI. Instrumentación de la vertebra fracturada; una opción válida de tratamiento en fracturas de la unión toraco-lumbar. Columna.2011; 1:3-9.

16. Jones TM, Anderson PA, Noonan KJ. Pediatric cervical spine trauma. J Am Acad Orthop Surg. 2011;19(10):600-11.

17. Nowak DD, Lee JK, Gelb DE, Poelstra KA, Ludwig SC. Central cord syndrome. J Am Acad Orthop Surg. 2009;17(12):756-65.

18. Cohen ME, Ditunno JF Jr, Donovan WH, Maynard FM Jr. A test of the 1992 International Standards for Neurological and Functional Classification of Spinal Cord Injury. Spinal Cord. 1998;36(8):554-60

19. Kirshblum SC, Waring W, Biering-Sorensen F, Burns SP, Johansen M, Schmidt-Read M, et al. Reference for the 2011 revision of the International Standards for Neurological Classification of Spinal Cord Injury. J Spinal Cord Med. 2011;34(6):547-54

20. Waring WP 3rd, Biering-Sorensen F, Burns S, Donovan W, Graves D, Jha A, et al. 2009 review and revisions of the international standards for the neurological classification of spinal cord injury. J Spinal Cord Med. 2010;33(4):346-52.

21. McKinley W, Santos K, Meade M, Brooke K. Incidence and outcomes of spinal cord injury clinical syndromes. J Spinal Cord Med. 2007;30(3):215-24.

22. Nielsen JB, Crone $\mathrm{C}$, Hultborn $\mathrm{H}$. The spinal pathophysiology of spasticity-from a basic science point of view. Acta Physiol (Oxf). 2007;189(2):171-80.

23. Palapa L, Vallejo S, Casas G. Tratamiento por vía anterior de las lesiones inestables de la columna toracolumbar. Acta Ortop Mex. 2002;16(5):245-52.
24. Acosta FL Jr, Aryan HE, Taylor WR, Ames CP. Kyphoplasty-augmented short-segment pedicle screw fixation of traumatic lumbar burst fractures: initial clinical experience and literature review. Neurosurg Focus. 2005;18(3):e9.

25. Alanay A, Acaroglu E, Yazici M, Oznur A, Surat A. Short-segment pedicle instrumentation of thoracolumbar burst fractures: does transpedicular intracorporeal grafting prevent early failure? Spine (Phila Pa 1976). 2001;26(2):213-7.

26. Mahar A, Kim C, Wedemeyer M, Mitsunaga L, Odell T, Johnson B, et al. Short-segment fixation of lumbar burst fractures using pedicle fixation at the level of the fracture. Spine (Phila Pa 1976). 2007;32(14):1503-7.

27. Atlas $S W$, Regenbogen $V$, Rogers LF, Kim KS. The radiographic characterization of burst fractures of the spine. AJR Am J Roentgenol. 1986;147(3):575-82.

28. Been HD, Bouma GJ. Comparison of two types of surgery for thoraco-lumbar burst fractures: combined anterior and posterior stabilisation vs. posterior instrumentation only. Acta Neurochir (Wien). 1999;141(4):349-57.

29. Carl AL, Tromanhauser SG, Roger DJ. Pedicle screw instrumentation for thoracolumbar burst fractures and fracture-dislocations. Spine (Phila Pa 1976). 1992;17(Suppl 8):S317-24.

30. Chiba M, McLain RF, Yerby SA, MoseleyTA, SmithTS, Benson DR. Short-segment pedicle instrumentation. Biomechanical analysis of supplemental hook fixation. Spine (Phila Pa 1976). 1996;21(3):288-94.

31. Vaccaro AR, Lehman RA Jr, Hurlbert RJ, Anderson PA, Harris M, Hedlund R, et al. A new classification of thoracolumbar injuries: the importance of injury morphology, the integrity of the posterior ligamentous complex, and neurologic status. Spine (Phila Pa 1976). 2005;30(20):2325-33.

32. Ferguson RL, Allen BL Jr. A mechanistic classification of thoracolumbar spine fractures. Clin Orthop Relat Res. 1984;(189):77-88.

33. Louis R. Spinal stability as defined by the three-column spine concept. Anat Clin 1985:7(1):33-42.

34. World Medical Association. WMA Declaration of Helsinki Ethical Principles for Medical Research Involving Human Subjects. Disponible en: http://www.wma.net// en/30publications/10policies/b3/.

35. Blumer CE, Quine S. Prevalence of spinal cord injury: an international comparison. Neuroepidemiology. 1995;14(5):258-68.

36. Cisneros DF. Diagnostico situacional del servicio, productividad 1999, servicio de cirugía de columna HTOLV. IMSS. 2000:22(9):23-7.

37. Maharaj JC. Epidemiology of spinal cord paralysis in Fiji: 1985-1994. Spinal Cord. 1996;34(9):549-59 